\title{
ASSESSING THE ENERGY EFFICIENCY OF AN ELECTRIC CAR
}

\author{
František Synák ${ }^{1, *}$, Matej Kučera ${ }^{2}$, Tomáš Skrúcaný ${ }^{1}$ \\ ${ }^{1}$ Department of Road and Urban Transport, Faculty of Operation and Economics of Transport and Communications, \\ University of Zilina, Zilina, Slovakia \\ ${ }^{2}$ Department of Measurement and Applied Electrical Engineering, Faculty of Electrical Engineering and Information \\ Technology, University of Zilina, Zilina, Slovakia
}

*E-mail of corresponding author: frantisek.synak@fpedas.uniza.sk

\section{Resume}

Electric car does not supply all the electric energy, obtained from the electric network, to the wheels in the form of mechanical energy. During such a transformation, a part of this energy is lost. The article endeavours to determine the energy efficiency of selected electric car. The electric car used for measurements is not from the batch production since that is a vehicle designed at University of Zilina. The efficiency has been observed while driving under the conditions of amended methodology of New European Driving Cycle (NEDC). The measured value of electric car's efficiency is being analyzed from the energy consumption, as well as emission production, points of view.

Available online: https://doi.org/10.26552/com.C.2021.1.A1-A13

\section{Article info}

Received 31 March 2020

Accepted 16 May 2020

Online 22 October 2020

\section{Keywords:}

electric car, energy efficiency, emissions, road traffic

\section{Introduction}

Energy input to an electric car in the form of electric energy obtained from the electric network is regulated before being supplied to the wheels in the form mechanical energy; there is a change in the value of electric current and voltage and it is further stored in the accumulator and transformed into mechanical energy in the electric motor. These processes are connected to energy losses [1]. Scientific publications, in many cases, pay attention only to particular components of electric cars, mostly to energy efficiency of electric car's batteries [2-4], or to efficiency of hybrid vehicles [5-7].

The article aims to determine the energy efficiency of an electric car. Through the measurements, the amount of energy obtained from the electric network and the amount of energy supplied to the dynamometer's cylinders, by means of which the measurements were performed, have been compared. The value of energy efficiency of electric car affects several aspects. One of those aspects is the amount of energy consumed that is needed for overcoming a certain distance. For instance, when increasing the overall energy efficiency of electric car from $60 \%$ to $80 \%$, the energy consumption needed for $100 \mathrm{~km}$ to be driven would decrease by $20 \%$. In the case of average value of energy consumption of $20 \mathrm{kWh} .100 \mathrm{~km}^{-1}$, the 20\%-increase in efficiency would lead to decrease in energy consumption to $16 \mathrm{kWh} .100 \mathrm{~km}^{-1}$. What is more, every single $\mathrm{kWh}$ of electric energy consumed is connected with a certain amount of emissions produced, certain amount of nonrenewable energy resources consumed as well as certain amount of money spent on electric energy purchase [8-9].

The value of energy efficiency of electric car also affects the value of its coasting, or the needed capacity of electric car's batteries. Such a capacity closely relates to mass of the batteries. Increasing of battery capacity by 10 $\mathrm{kWh}$ means increase in mass of electric car by about 15 $\mathrm{kg}$ depending on the battery type. Such an increase can cause a difference in energy consumption, according to driving cycle parameters [10], up to $1 \mathrm{kWh} .100 \mathrm{~km}^{-1}$. When increasing the battery capacity, as well as the unladed mass of electric car, it leads to decrease in vehicle load capacity [11].

There is also a relation between the amount of emissions produced and the energy efficiency and consumption of an electric car [12]. A theoretical amount of selected emissions produced in connection with production of electric energy used for the electric car to be driven has been calculated, as well. Such a theoretical production of emissions of carbon dioxide, carbon monoxide, nitrogen oxides and particulate matters has been calculated per unit of energy consumed. The reason of the comparison of emissions produced by electric cars and combustion engine vehicles lies in the fact that the road transport is a major producer of the abovementioned gaseous emissions [13].

Carbon dioxide $\mathrm{CO}_{2}$ is considered as a gas causing the greenhouse effect with approximately $55 \%$ share on it. In the EU, the transport is the only sector in which there 


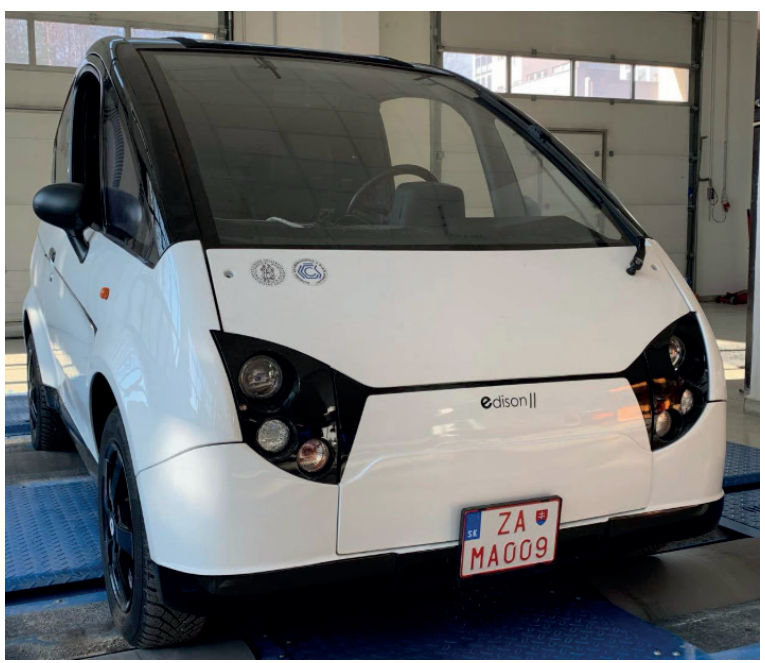

Figure 1 Vehicle used for measuring

Table 1 Technical parameters of vehicle used for measuring [16]

parameter
electric motor
controller
batteries
gross vehicle weight
maximal speed
frame
body
length
wheelbase
width

was no reduction, but an increase in the greenhouse gases production when comparing to 1990 [13].

Carbon monoxide CO is a colourless and odourless gas, which is highly toxic for humans. It can bind with haemoglobin up to 300 times more efficiently than oxygen resulting in a limited transportation of oxygen from lungs into the tissues and thus the tissues and cells are being damaged. The longer exposure of humans, together with its higher concentration in blood, causes coma or death [14].

Specific chemical compounds, known as nitrogen oxides $\mathrm{NO}_{\mathrm{x}}$, affect the greenhouse effect, acid rains and health of population negatively.

Particulate matters PM have a negative impact on population's health. They also cause faster ice melting due to their higher absorption of light resulting from black colour [15].

Concerning the electric car operation, the amounts of emissions produced have been compared to values calculated for combustion engine vehicles.

Devices through which is the energy for the wheels to be driven coming can be divided into those that operate only with electric energy and those that operate only with mechanical energy. There is an exception seen in the electric motor's shaft in which the transformation of electric energy to mechanical energy during the wheel value

AC, AKOE $15 / 30 \mathrm{~kW}, 80 \mathrm{~V}$

Curtis 1238

Thunder Sky LiFeYPO4, 300 Ah

$1300 \mathrm{~kg}$

$80 \mathrm{~km} \cdot \mathrm{h}^{-1}$

steel tube space frame

steel/plastic

$3100 \mathrm{~mm}$

$2130 \mathrm{~mm}$

$1550 \mathrm{~mm}$

driving mode and the transformation of mechanical energy to electric energy during the recuperation mode, are being under way.

The electric car used for measurements has all of its devices, from the electric socket up to electric motor's shaft, operating only with electric energy and from the electric motor's shaft up to wheels, operating only with mechanical energy. Not taking into consideration mechanical losses, conducting the vehicle coasting test on the dynamometer has enabled to determine the efficiency of particular parts of vehicle that operate with electric or mechanical energy. The mechanical losses in electric motor are caused only by two rolling bearings and thus, it can be assumed that they are not of significant value and their share on the result accuracy can be neglected.

The article contributes an insight into the efficiency of energy transmission by electric cars from several points of view.

\section{Measurement methodology}

In the form of mechanical energy, there has been the transmission energy efficiency, taken from electric energy to dynamometer's cylinders, determined. 


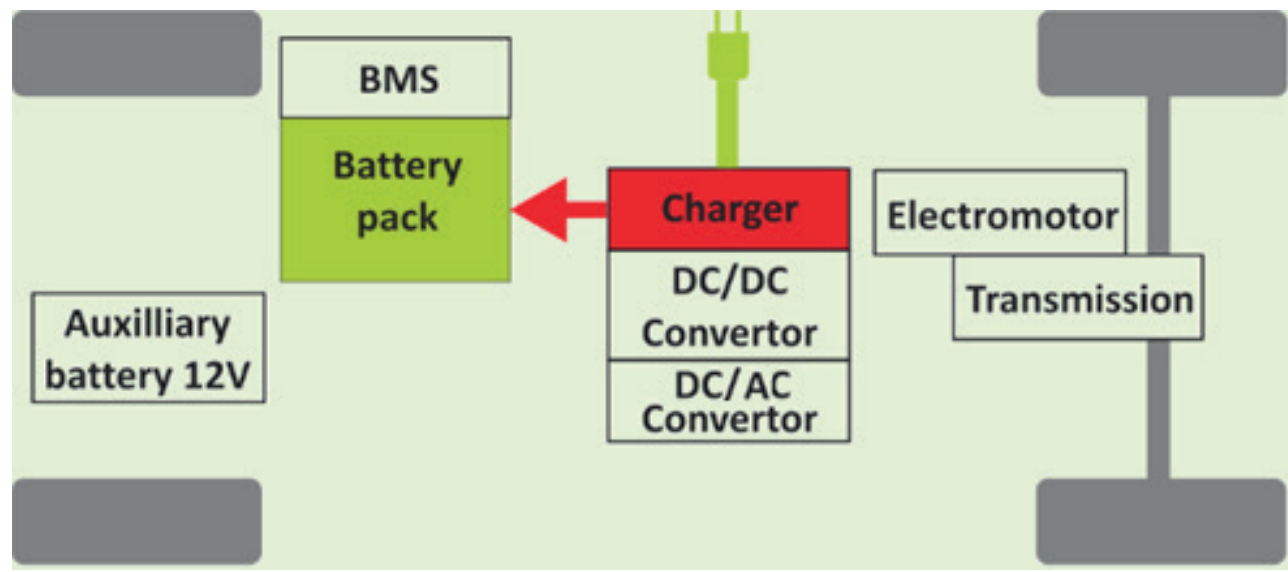

Figure 2 Mode of battery charging [16]

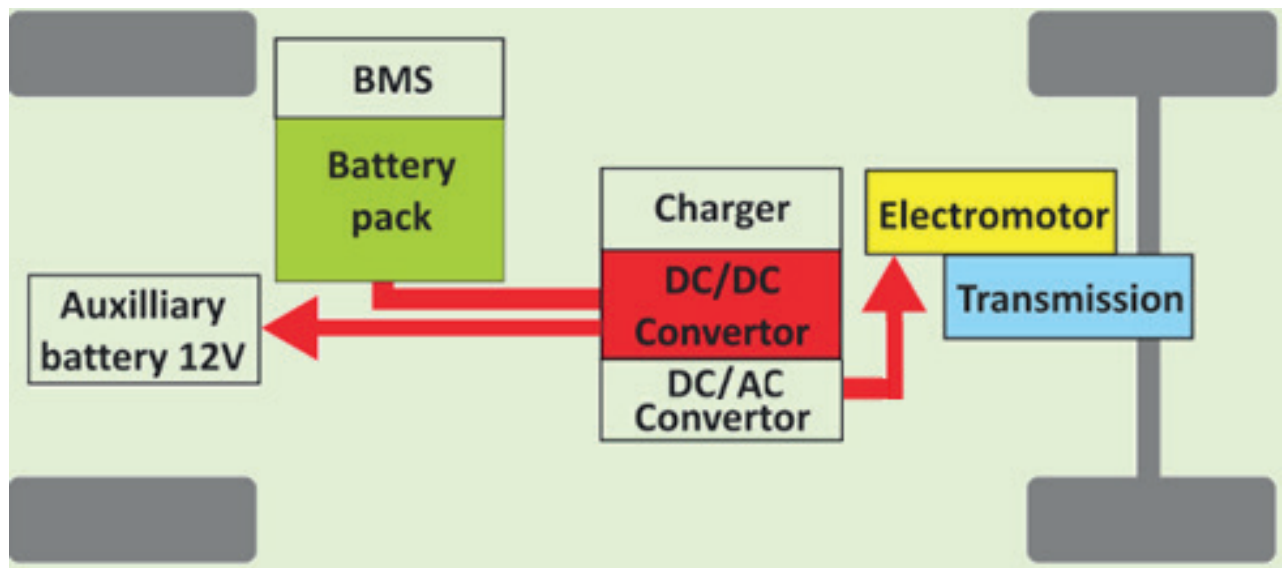

Figure 3 Mode of wheel driving [16]

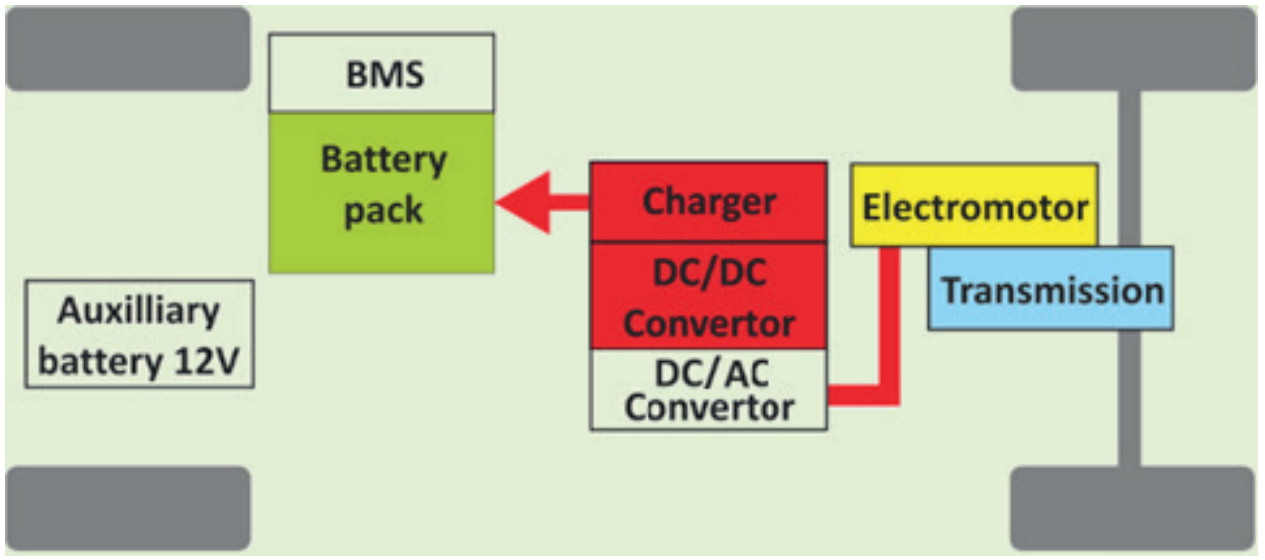

Figure 4 Recuperation mode [16]

\subsection{Vehicle used for measuring}

Figure 1 shows the vehicle used for measuring. It is called Edison II and its production was at University of Zilina.

The technical parameters are given in Table 1.

The basic vehicle modes comprise charging, wheel driving and recuperation. Particular modes are controlled via battery management system. The energy flow during the charging mode is displayed in Figure 2.
As seen from Figure 2, while charging, the energy is transmitted from the socket to the battery pack via charger together with convertor.

Figure 3 displays the flow of energy while wheel driving.

During the mode of wheel driving, the electric energy from batteries is being transmitted through the DC/DC convector into the electric motor in which it is converted into mechanical energy. This energy is further transmitted through the planetary gear to the wheels. Electric energy in 


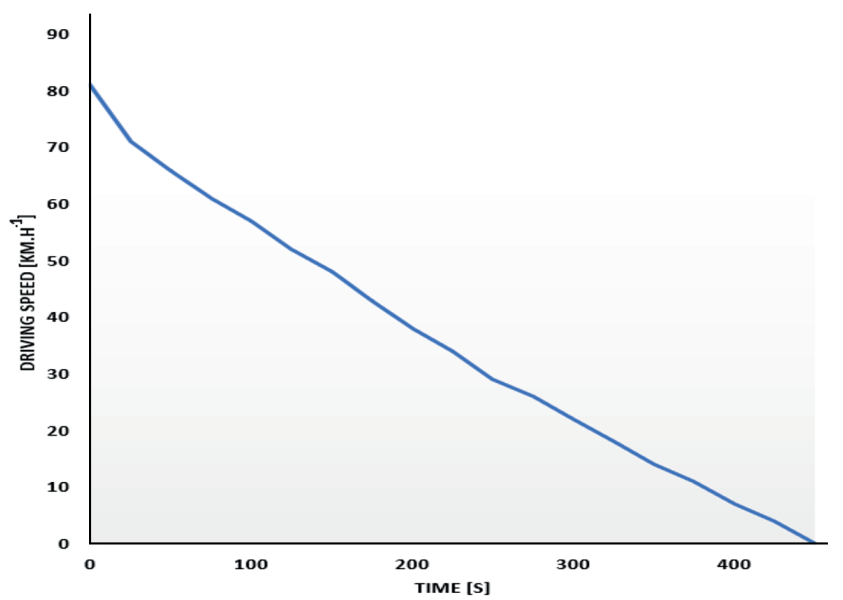

Figure 5 Vehicle deceleration during coasting deceleration measurement

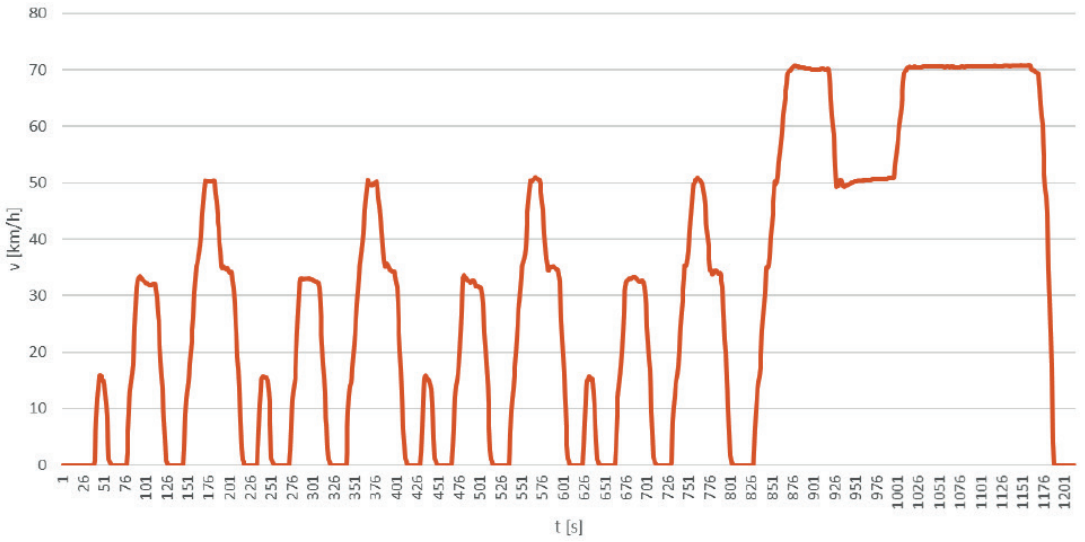

Figure 6 Real driving speed according to amended methodology of the NEDC

the vehicle is also necessary for on-board computer, vehicle headlights, windscreens and other devices to be connected. It is, therefore, also transmitted from the DC/DC convector to $12 \mathrm{~V}$ auxiliary battery intended for the above-mentioned devices to be plugged-in.

While vehicle is running, there is no need to bring the driving force on the wheels. It can be seen while engine braking for example when driving downhill [17]. The energy flow during the recuperation is shown in Figure 4.

During the mode of energy recuperation, mechanical energy from the wheels is being transmitted through the transmission to electric motor. The electric motor converts the mechanical energy into electric energy, which is further transmitted through the controller and DC/DC convertor to the charger and subsequently to the batteries.

\subsection{Device used for measuring}

The device used for measuring was a dynamometer MAHA MSR 1050. The measurement deviation of this device is $+/-2 \%$ from the measured value according to the manufacturer. The dynamometer enables a simulation of a vehicle driving by simulating the real driving resistances via braking or cylinder driving. At the same time, it provides the better accuracy in comparison to measurements while road driving and it also enables to record a value of mechanical energy delivered from the wheels on its cylinders [18]. In order to have the cylinder values at the level of situation in which a vehicle is road driving, it is necessary to introduce these values into the cylinder test station's control computer. The values are achieved by the coasting deceleration measurement of vehicle resistance under the conditions of Standard EN 300556 [19]. Such measurement relies on a vehicle with prescribed laden mass, which is accelerated up to the speed about of $80 \mathrm{~km} . \mathrm{h}^{-1}$; disconnection between the engine and wheels, and on the recording of vehicle coasting [20]. Figure 5 depicts the vehicle deceleration during measurement.

The recorded vehicle speed that depends on the time of disconnection between the engine and wheels is further introduced into the cylinder test station's computer. Based on these values and measurement results, the computer sets values of deceleration or acceleration directly at the cylinders during the particular driving modes. At the same time, based on the coasting test, the computer is calculating the difference in values of the rolling resistance between the road and cylinder driving since the rolling resistance has an increasing character on the cylinders compared to road surface. Thus, the cylinder test station can fully provide a road driving simulation [21]. 


\subsection{Measurement process}

Measurement of the transmission energy efficiency has been performed while the vehicle driving according to amended new European driving cycle, known as NEDC [22]. Such amendment of NEDC cycle comprises a change in the maximum driving speed from $121 \mathrm{~km} \cdot \mathrm{h}^{-1}$ to 70 $\mathrm{km} \cdot \mathrm{h}^{-1}$. The instantaneous speed deviation, opposite to the prescribed one, has been of $\pm 2 \mathrm{~km} \cdot \mathrm{h}^{-1}$. The real course of driving, according to amended methodology of the NEDC, is shown in Figure 6.

While vehicle driving under the NEDC conditions, various driving modes are changing such as vehicle acceleration, driving at the stabilised speed, or vehicle deceleration as seen in Figure 5. Thus, while driving, there are both driving modes active, wheel driving and recuperation modes.

According to conditions of the NEDC, the transmission energy efficiency has been determined while vehicle driving under the comparison of the amount of energy supplied to vehicle from the electrical socket and energy delivered from the vehicle into dynamometer's cylinders.

An electricity meter has been used for measuring the energy delivered from the socket since it is a designated measuring device, which is tested according to [23]. The electricity meter displays the amount of energy consumed in kilowatt-hours. A kilowatt-hour is not a part of the International System of Units (SI), although it is derived from the watt unit. According to SI, the unit that corresponds to the energy is a joule. One joule is one watt-second. In order to calculate the amount of energy delivered in the joules, the relation below has been used:

$$
E E_{s}=E E_{s k} \cdot 36 \cdot 10^{5},
$$

where:

$E E s$ - electric energy delivered in [J], $E E_{s k}$ - electric energy delivered in [kWh].

Value of electric energy delivered has been determined by subtraction of the value seen in the electricity meter at the end of charging from the value seen at the beginning. While charging the electric car from the socket, to which the electricity meter was connected, there was no electric energy taken by any other device.

The dynamometer has recorded the power supplied to the cylinders by the wheels 10 times per second. In order to compare the energy supplied to the dynamometer's cylinders with the energy delivered from the socket, it was necessary to calculate the energy supplied to the cylinders firstly according to relation:

$$
E M_{s c}=\frac{P_{c}}{T_{m}},
$$

where:

$E M_{s r}$ - mechanical energy supplied to the cylinders [kWh],

$P_{c}$ - average value of power supplied to the dynamometer's cylinders [kW],

$T_{m}$ - time of measuring [hours].
Subsequently, the energy supplied to the cylinders and calculated in $\mathrm{kWh}$ was recalculated into joules according to relation (1).

By the theoretical calculations, it was also possible to determine an approximate energy loss between the electric socket and electric motor's shaft as well as between the electric motor's shaft and cylinders of dynamometer. This calculation has been made based on the measurement between the power of electric motor's shaft and power transmitted on the dynamometer's cylinders.

\subsection{Calculation of average energy consumption}

Average energy consumption, given per $100 \mathrm{~km}$ of the distance driven, has been determined, as well. Based on the average energy consumption per one amended NEDC cycle and its average length, the energy consumption has been calculated. On the grounds of transmission energy efficiency, the energy consumption has been calculated as an energy consumption taken from the socket, energy consumption in the electric motor's shaft and energy consumption on the dynamometer's cylinders.

The energy consumption on the cylinders of dynamometer has been calculated according to relation:

$E C_{c}=\frac{E_{d c}}{D}$

where:

$E C_{c}$ - energy consumption on dynamometer's cylinders [kJ. $100 \mathrm{~km}^{-1}$,

$E_{d c}$ - energy delivered to dynamometer's cylinders [kJ],

$D$ - trajectory driven while measuring [m] [24].

Similarly, the energy consumption in connection with energy taken from the electric socket has been calculated, however, there is a difference. Instead of energy delivered to the dynamometer's cylinders, the energy taken from the socket has been taken into consideration within the formula of calculation.

In order to calculate the energy consumption in connection with electric motor shaft, the same relation has been used, though there has been also the transmission energy efficiency from the electric motor's shaft on the dynamometer's cylinders borne in mind.

\section{Results}

Figure 7 displays the curves showing the courses of power measured by Edison II vehicle on the cylinder test station MAHA MSR 1050. The abscissa displays the driving speed, the left ordinate axis displays the power and the right ordinate axis shows the torque.

Data from Figure 7 can also be obtained from the control computer of MAHA MSR 1050 numerically. By averaging the data values of power on the dynamometer's cylinders and torque, it is possible to find out that the transmission power efficiency from the electric motor's 


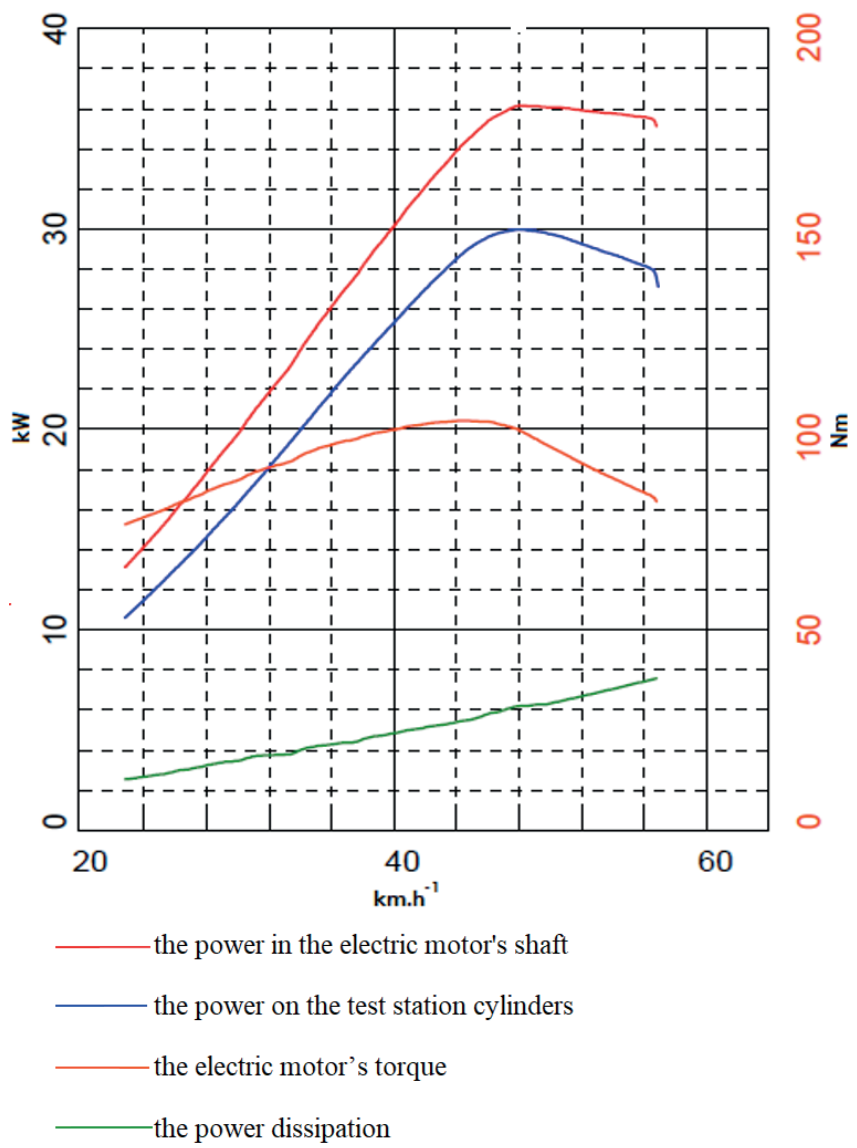

Figure 7 The course of power and torque in Edison vehicle

Table 2 The values of selected parameters during measurement

\begin{tabular}{ccccc}
\hline number of measuring & $\begin{array}{c}\text { time of measuring } \\
(\mathrm{s})\end{array}$ & $\begin{array}{c}\text { average driving speed } \\
\left(\mathrm{km} \cdot \mathrm{h}^{-1}\right)\end{array}$ & $\begin{array}{c}\text { distance driven } \\
(\mathrm{m})\end{array}$ & $\begin{array}{c}\text { average cylinders power } \\
(\mathrm{kW})\end{array}$ \\
\hline 1. & 1324 & 28.14 & 10349 & 2.643 \\
2. & 1345 & 27.97 & 10449 & 2.607 \\
3. & 1321 & 27.82 & 10208 & 2.640 \\
4. & 1336 & 28.02 & 10398 & 2.617 \\
5. & 5394 & 27.03 & 40499 & 2.563 \\
\hline
\end{tabular}

shaft on dynamometer's cylinders is $82 \%$. Thus, there is an energy loss of $18 \%$ between the electric motor's shaft and cylinders. When assessing results of calculations, it is necessary to take into consideration that besides losses in the vehicle there are also losses caused by the wheels' rolling resistance along the dynamometer's cylinders. Therefore, the calculation cannot be regarded as accurate but approximate [25]. The values measured during one amended NEDC cycle correspond to measurements from the number 1 up to 4 and the results measured during four successive amended NEDC cycles and subsequent charging correspond to measurement number 5 .

The parameters of particular measurements according to amended NEDC cycle are shown in Table 2.

Results of the transmission energy efficiency are given in Table 3.
The transmission energy efficiency from the electric socket on the dynamometer's cylinders has been $45 \%$ that is quite a low value [26]. However, it is necessary to bear in mind that there is a rolling resistance added into the efficiency [27]. On the other hand, the rolling resistance, as well as the other driving resistances, is always seen when vehicle driving.

Table 4 shows the value of energy according to the place of its dissipation, that means its conversion into other energy than mechanical, supplied to the dynamometer's cylinders.

As seen from Table 4, there are large energy losses between the socket and electric motor's shaft.

Based on the data from Tables 2 and 3, it is possible to calculate an average energy consumption of Edison II per $100 \mathrm{~km}$ while driving according to amended NEDC cycle. 
Table 3 Transmission energy efficiency from the electric socket on dynamometer's cylinders

\begin{tabular}{cccc}
\hline number of measuring & $\begin{array}{c}\text { energy delivered } \\
(\mathrm{kJ})\end{array}$ & $\begin{array}{c}\text { energy on cylinders } \\
(\mathrm{kJ})\end{array}$ & $\begin{array}{c}\text { efficiency } \\
(\%)\end{array}$ \\
\hline 1. & 7711 & 3499 & 45 \\
2. & 7715 & 3506 & 45 \\
3. & 7672 & 3488 & 3496 \\
4. & 7711 & 3524 & 45 \\
5. & 30924 & 13824 & 45 \\
\hline
\end{tabular}

Table 4 Reduction of electric car efficiency

\begin{tabular}{|c|c|c|c|c|c|}
\hline $\begin{array}{l}\text { number of } \\
\text { measuring }\end{array}$ & $\begin{array}{l}\text { overall energy lost } \\
(\mathrm{kJ})\end{array}$ & $\begin{array}{c}\text { energy lost in front } \\
\text { of the electric } \\
\text { motor's shaft } \\
(\mathrm{kJ})\end{array}$ & $\begin{array}{l}\text { energy lost in front } \\
\text { of the electric } \\
\text { motor's shaft (\%) }\end{array}$ & $\begin{array}{l}\text { energy lost behind } \\
\text { the electric motor's } \\
\text { shaft }(\mathrm{kJ})\end{array}$ & $\begin{array}{c}\text { energy lost behind } \\
\text { the electric motor's } \\
\text { shaft (\%) }\end{array}$ \\
\hline 1. & 4212 & 3454 & 82 & 758 & 18 \\
\hline 2. & 4209 & 3451 & 82 & 758 & 18 \\
\hline 3. & 4184 & 3431 & 82 & 753 & 18 \\
\hline 4. & 4215 & 3456 & 82 & 759 & 18 \\
\hline 5. & 17100 & 14022 & 82 & 3078 & 18 \\
\hline
\end{tabular}

Table 5 Average energy consumption

\begin{tabular}{cccc}
\hline $\begin{array}{c}\text { place of energy consumption } \\
\text { calculation }\end{array}$ & $\begin{array}{c}\text { dynamometer's cylinders } \\
\left(\mathrm{kJ} .100 \mathrm{~km}^{-1}\right)\end{array}$ & $\begin{array}{c}\text { electric motor's shaft } \\
\left(\mathrm{kJ} .100 \mathrm{~km}^{-1}\right)\end{array}$ & $\begin{array}{c}\text { electric socket } \\
\left(\mathrm{kJ} .100 \mathrm{~km}^{-1}\right)\end{array}$ \\
\hline energy consumption & 33958 & 40071 & 75373 \\
\hline
\end{tabular}

Table 6 Emission production depending on how a vehicle is driven

\begin{tabular}{ccccc}
\hline \multirow{2}{*}{ vehicle } & \multicolumn{3}{c}{ emission $\left(\mathrm{g} . \mathrm{kwh}^{-1}\right)$} \\
\cline { 2 - 5 } & $\mathrm{CO}$ & $\mathrm{CO}_{2}$ & $\mathrm{NO}_{\mathrm{x}}$ & 0.4 \\
\hline heavy goods vehicles & 1.5 & - & 0.01 & 0.06 \\
SI engines for M1 vehicles & 0.989 & 253 & 0.06 & 0.019 \\
$\begin{array}{c}\text { electric energy from } \\
\text { power plants in EU }\end{array}$ & 0.186 & 459.2 & & \\
\hline
\end{tabular}

The average energy consumption pursuant to the above-mentioned conditions is given in Table 5 .

As seen from Table 5, the wheels' energy consumption has been $45 \%$ of the energy consumption taken from the electric socket. The energy consumption of electric motor's shaft represented $53 \%$ of the energy consumption of electric socket. That means there was $47 \%$ energy from the electric socket lost between the electric socket and electric motor's shaft.

Publication [28] shows the theoretical calculation of the amount of selected emissions produced per energy unit. There is emission production compared between the combustion engine vehicles and vehicles with electric motors. Concerning the vehicles with electric motor, the data are calculated for electric energy made in European Union. Since the Standard [29] sets the emissions in kilowatt-hour, the data are also set so. Values have been calculated based on data from the Euro 6 standard and according to values given by the power plants in the case of electric cars. The data are calculated for the motor's shaft energy output and can be seen in Table 6 .

Concerning the heavy goods vehicles and SI engines for M1 vehicles, it is considered that only a certain part of the chemical energy from the fuel is converted into mechanical energy on the motor's shaft energy output, depending on the energy efficiency of combustion engine. On the other hand, in the case of electric cars, it is considered that all of the energy delivered from the electric socket is being converted into mechanical energy on the output of the motor's shaft. However, that is not a true fact as proved in the previous part of the article. Based on the measurement results, it is possible to add a value of theoretical production of selected emissions to Table 6 by taking into consideration the energy efficiency of energy transmission measured from the electric socket up to electric motor's shaft that is seen in Table 7. 
Table 7 Emission production depending on efficiency of electric car's transmission energy and how a vehicle is driven

\begin{tabular}{|c|c|c|c|c|}
\hline \multirow{2}{*}{ vehicle } & \multicolumn{4}{|c|}{ emission (g.kwh ${ }^{-1}$ ) } \\
\hline & $\mathrm{CO}$ & $\mathrm{CO}_{2}$ & $\mathrm{NO}_{\mathrm{x}}$ & PM \\
\hline heavy goods vehicles & 1.5 & - & 0.4 & 0.01 \\
\hline SI engines for M1 vehicles & 0.989 & 253 & 0.06 & 0.06 \\
\hline $\begin{array}{l}\text { electric energy from power plants in } \\
\text { EU, } 100 \% \text { efficiency }\end{array}$ & 0.186 & 459.2 & 0.348 & 0.019 \\
\hline $\begin{array}{l}\text { electric energy from power plants in } \\
\text { EU, real efficiency }\end{array}$ & 0.273 & 675 & 0.512 & 0.028 \\
\hline
\end{tabular}

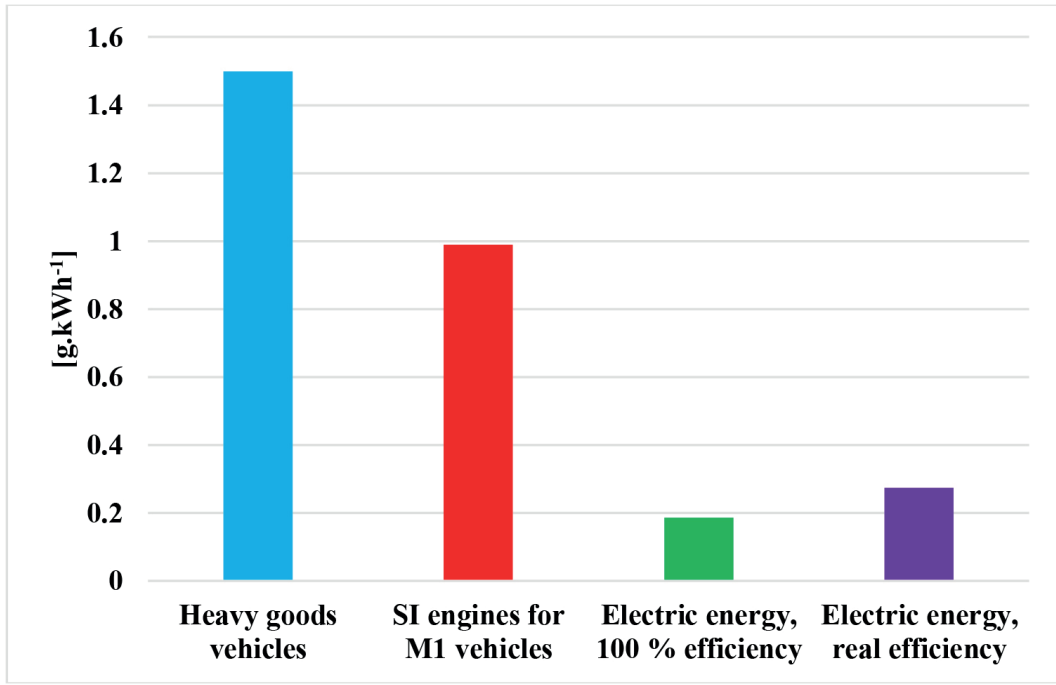

Figure 8 Comparison of theoretical CO production

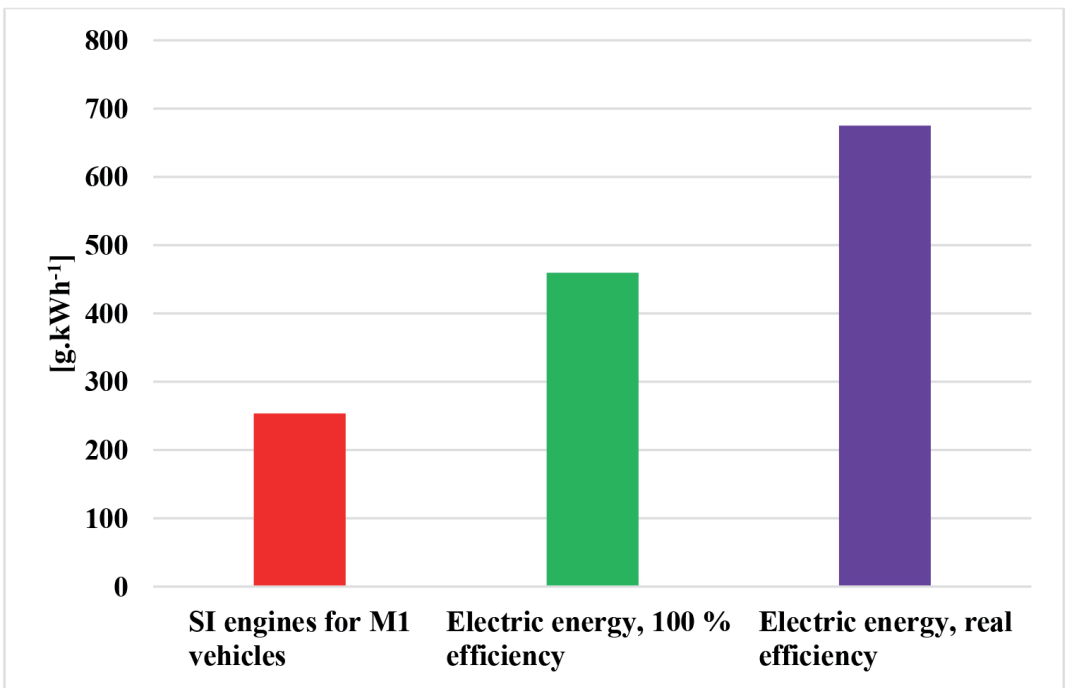

Figure 9 Comparison of theoretical $\mathrm{CO}_{2}$ production

For better transparency, the results are also given in graphs in Figures 8-11.

As seen from Figure 8, the electric cars should not produce more $\mathrm{CO}$ than the combustion engine vehicles. $\mathrm{CO}$ is a gas, which affects the health of population negatively, and thus, it is important that electric cars do not produce $\mathrm{CO}$ directly while running.

Figure 9 shows the comparison of $\mathrm{CO}_{2}$ production. Since the $\mathrm{CO}_{2}$ production is not being assessed within the heavy goods vehicles, it is not given in Figure 9 either.
The theoretical production of the greenhouse gas $\mathrm{CO}_{2}$, relating to the operation of electric cars is significantly higher as for the SI engine vehicles. When taking into consideration the real efficiency of energy transmission from the electric socket on the electric motor's shaft, the theoretical production of $\mathrm{CO}_{2}$ within the electric cars has increased from the value of 459 g.kWh ${ }^{-1}$ to 675 g. $\mathrm{kWh}^{-1}$. Considering the combustion engines, $\mathrm{CO}_{2}$ production is being proportional to the fuel consumption [24]. Assuming the higher engine energy efficiency of heavy goods vehicles, 


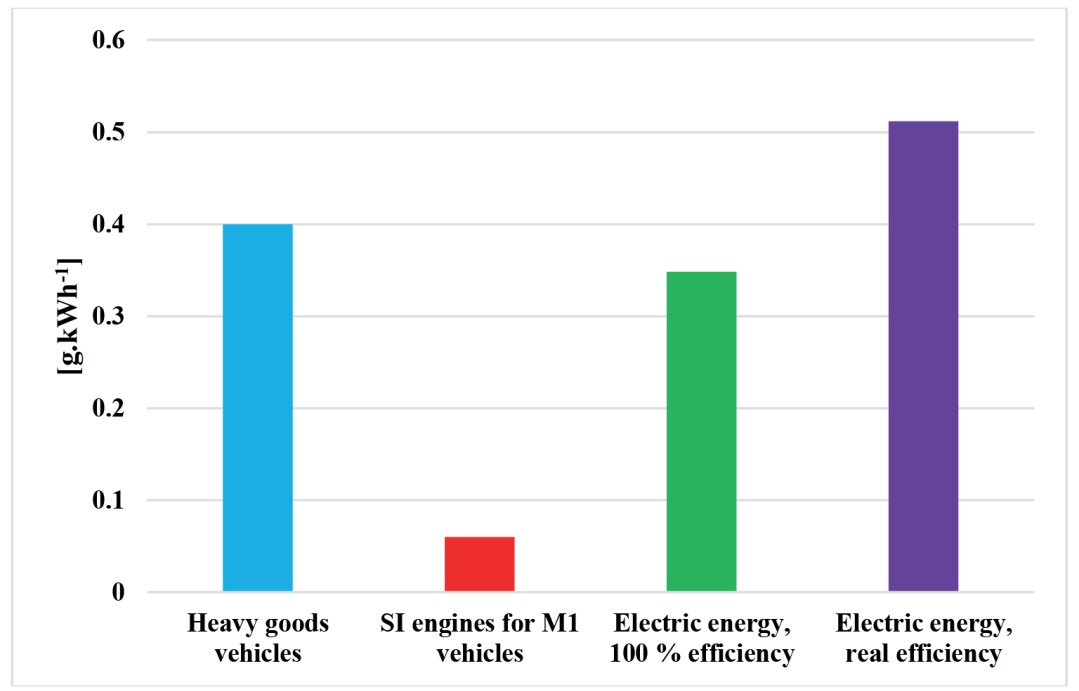

Figure 10 Comparison of theoretical $\mathrm{NO}_{x}$ production

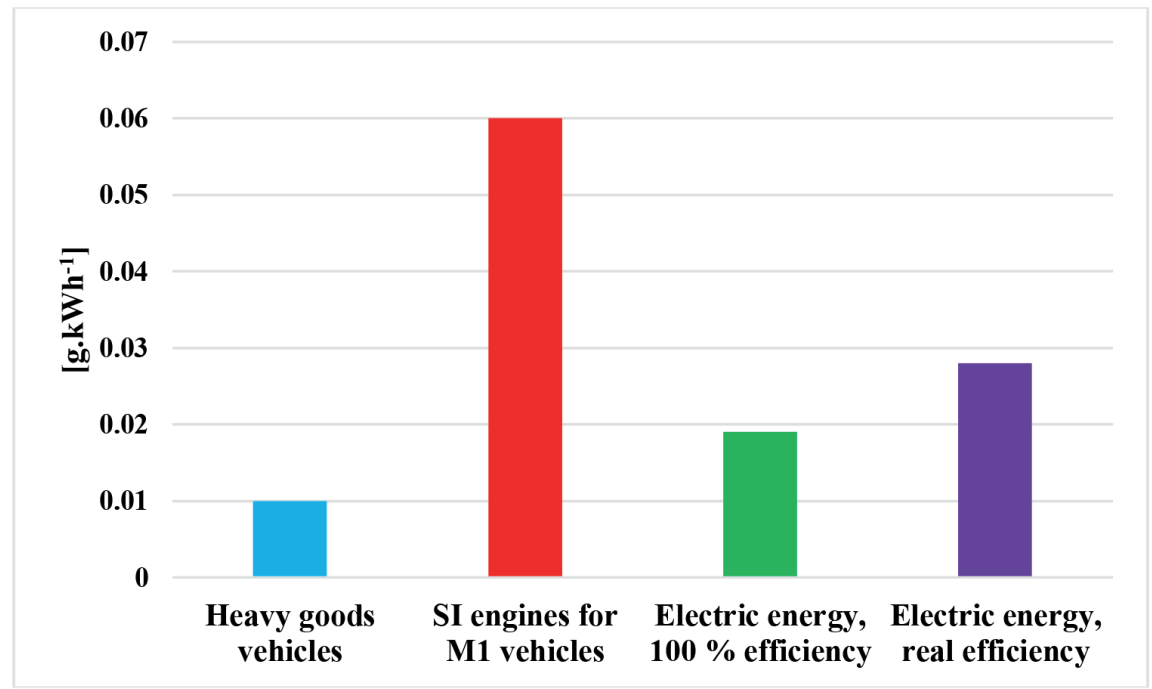

Figure 11 Comparison of theoretical PM production

it is possible to expect lower production of $\mathrm{CO}_{2}$ grams per one $\mathrm{kWh}$ within the framework of these vehicles.

After taking into consideration the real efficiency, the greatest producers of $\mathrm{NO}_{\mathrm{x}}$, albeit indirectly, are the electric vehicles.

The theoretical production of PM within the electric cars is higher than within the heavy goods vehicles, however, concerning the SI engines for M1 vehicles, it is lower.

\section{Discussion}

Concerning the electric cars, the comparison of values of the energy input and output has shown their energy efficiency issues.

The power measured on the Edison II has been higher (Figure 7) than the power given in its documentation (Table 1). The power in the documentation is the assumed one and, in the case of electric cars, there is a common phenomenon that the power measured is the higher than power given by the manufacturer [30]
The losses measured between the electric motor's shaft and dynamometer have reached $18 \%$ of energy transmitted. These losses are predominantly of mechanical character [31]. In comparison to combustion engine vehicles, such loss has shown as lower. Concerning the combustion engine vehicles, the losses reach up to $25 \%$ and more, mainly due to their construction design, primarily and foremost due to simplification of the transmission system [32]. The vehicle Edison II has a planetary transmission with three gears of speed. Thus, the transmission mechanism of a vehicle used has substantially fewer parts in which it could lead to mechanical losses [33].

Concerning particular measurements, the data from Table 1 slightly vary. While driving according to amended NEDC cycle, some deviations were noticed in time of measuring, average speed, distance driven and in an average value of power supplied to dynamometer's cylinders, as well. The reason of these deviations lies in a fact that drivers were not always driving precisely according to conditions of amended NEDC cycle. This requires a long time practice by the driver. However, the deviations between particular 
measurements do not have a negative impact on needs for the article's research.

The transmission energy efficiency from the electric socket on the dynamometer's cylinders was $45 \%$ under the conditions set in this article. It is quite a low value and it is necessary to take into consideration that the value was not measured on the wheels directly, but on the cylinders of dynamometer [34-35]. It means that the efficiency was decreased by the rolling resistance of tires along the cylinders. If the efficiency is increased by the rolling resistance, the transmission energy efficiency will be still low, up to $55 \%$ and less. The reason lies in various factors. The first one represents the charging during which it must lead to the voltage transformation and its rectification [36]. The second one is the storage of electric energy in accumulators and its further transmission through the DC/DC convertor into electric motor, as seen in Figure 3 [37-38]. There are also some energy losses depending on design of accumulator. The Li-ion accumulators have the efficiency of $80-90 \%$, the PB accumulators have 50 up to $92 \%$, and the NiMH accumulators have the efficiency of about $66 \%$ [39-41]. Thus, the storage and further deliver of electric energy from the accumulators are accompanied with energy losses. Those losses can be also seen between the engine and wheels due to mechanical resistances of the transmission system. The last place in which the losses can be seen is tire. However, there is a part of energy used for the on-board computer and other appliances to be plugged-in.

The measurements have been done at the surrounding temperature of about $22{ }^{\circ} \mathrm{C}$. In the case of lower temperatures, the efficiency would have lower values [42]. While driving according to amended NEDC cycle, there is also vehicle deceleration. Here, it can be assumed that the driving mode of recuperation, i.e. vehicle accumulator charging, is applied.

From Table 4 can be seen an obvious difference in average energy consumption if assessing it on the dynamometer's cylinders and as taken from the electric socket. The cylinders of dynamometer have the average energy consumption calculated as 33958 [kJ.100km $\left.{ }^{-1}\right]$, resp. $9.43 \mathrm{kWh} .100 \mathrm{~km}^{-1}$, the electric socket has had 75373 [kJ.100km-1], resp. $20.93 \mathrm{kWh} .100 \mathrm{~km}^{-1}$.

\section{Conclusion}

Measurements have shown a great difference between the amount of energy taken from the electric socket and amount of energy delivered to the dynamometer's cylinders.

Efficiency of the transmission energy from the electric socket on the dynamometer's cylinders has been $45 \%$ within the electric car used for the measurement. Thus, $55 \%$ of the energy taken from the electric socket has not been used for the wheels to be driven. In other words, under these conditions, only $5 \mathrm{kWh}$ from every $10 \mathrm{kWh}$ of energy taken from the electric socket is being delivered to wheels in the form of electric energy. This value of efficiency is relatively low. Such a value has been probably affected by using the vehicle of serial production. However, whether using serial or individual vehicles, the efficiency of energy transmission has a significant impact on energy efficiency of electric cars.

As also stated in the article's introduction, the devices through which the energy in electric car, used for the measurement, is coming can be divided into electric and mechanical ones. The electric devices especially include charger, convertors, battery pack, electric conductors and part of the electric motor's shaft (Figures 2 - 4). Mechanical parts consist predominantly of transmissions gear, shafts and wheel bearings. All of the vehicle's electrical parts, used in the measurement, are placed between the electric socket and electric motor's shaft and the mechanical parts are placed between the electric motor's shaft and wheels. Through the vehicle coasting driving test on the dynamometer it was possible to determine losses of mechanical energy between the electric motor's shaft and cylinders of dynamometer. The energy taken from the socket has been delivered to electric motor's shaft in the amount of $53 \%$. The losses have had up to $82 \%$ in electric devices and $18 \%$ in mechanical devices from the overall amount of energy lost. Thus, the electric part of a vehicle has had substantially higher share on the overall energy losses than its mechanical part. It is necessary to take into consideration that losses also have included a part of electric energy delivered from the electric socket that has been used for an on-board indicator to be plugged in. Lights, ventilators and other electronic devices have been switched off during the measurement.

The value of the electric car energy efficiency has a large impact on the harmful emission production, as well, as seen in Table 7 and in Figures 8-11. Knowing the value of efficiency of energy transmission from the electric socket onto the electric motor's shaft has enabled a comparison of theoretical production of selected emission production within the combustion engines as there has been a theoretical production of emission calculated for them having considered the engine's energy efficiency.

Concerning the theoretical production of $\mathrm{CO}$, a considerably lower CO production within the electric cars was found out, even having made calculations with the real efficiency of energy transmission onto the electric motor's shaft. It is important to know that the electric cars do not produce $\mathrm{CO}$ directly during the driving, but indirectly, during the electric energy production. Thus, to introduce the electric car driving in the cities is positive.

Concerning the $\mathrm{CO}_{2}$ production, the highest theoretical value of production of gas causing the greenhouse effect has been calculated within the production of electric energy in relation to operation of electric vehicles. Therefore, it can be said that from the local point of view the electric vehicles can contribute to reduction of $\mathrm{CO}$ concentration in densely populated areas. However, from the global point of view, using the electric vehicles does not weigh in on slowing down global warming.

Taking into consideration the efficiency of energy transmission from the electric socket onto the electric 
motor's shaft, the theoretical production of nitrogen oxides has increased from the value of 0.348 g. $\mathrm{kWh}^{-1}$ up to 0.512 g.kWh ${ }^{-1}$ (Figure 10). Thus, when considering such energy efficiency, the indirect production of nitrogen oxides by electric cars is higher than in the case of heavy goods vehicles.

Due to considering the real efficiency of energy transmission from the electric socket onto the electric motor's shaft, the theoretical production of PM within electric cars has increased from the value of $0.019 \mathrm{~g} . \mathrm{kWh}^{-1}$ up to $0.028 \mathrm{~g} . \mathrm{kWh}^{-1}$ (Figure 11).
Results of this article point out that it is important to take the energy efficiency into consideration when thinking about electric cars

\section{Acknowledgement}

This contribution/publication is the result of the project implementation:

VEGA no. 1/0436/18 - Externalities in road transport, an origin, causes and economic impacts of transport measures.

\section{References}

[1] WU, Z., LING, R., TANG, R. Dynamic battery equalization with energy and time efficiency for electric vehicles. Energy Procedia [online]. 2017, 141, p. 937-948. ISSN 1876-6102. Available from: https://doi.org/10.1016/j.energy.2017.09.129

[2] HAMSAVARTHINI, Y., KANTHALAKSHMI, S. Technologies in battery management system - a review. International Journal of Scientific and Technology Research. 2020, 9(2), p. 1324-1330. ISSN 2277-8616.

[3] AJANOVIC, A., HAAS, R. Economic and environmental prospects for battery electric- and fuel cell vehicles: a review. Fuel cells [online]. 2019, 19(5), p. 515-529. eISSN 1615-6854. Available from: https://doi.org/10.1002/fuce.201800171

[4] HUANG, Y. Q., MEI, P., LU, Y. J., HUANG, R., YU, X., CHEN, Z., ROSKILLY, A. P. A novel approach for Lithium-ion battery thermal management with streamline shape mini channel cooling plates. Applied Thermal Engineering [online]. 2019, 157, 113623. ISSN 1359-4311. Available from: https://doi.org/10.1016/j.applthermaleng.2019.04.033

[5] WANG, S., LI, J., SHI, D., Sun, X., Yao, Y. Energy management strategy of dual planetary hybrid electric vehicle based on optimal transmission efficiency. Journal of Theoretical and Applied Mechanics [online]. 2019, 57(2), p. 383-396. ISSN 1429-2955, eISSN 2543-6309. Available from: https://doi.org/10.15632/jtam-pl/104591

[6] CHEN, B., EVANGELOU, SA., LOT, R. Hybrid electric vehicle two-step fuel efficiency optimization with decoupled energy management and speed control. IEEE Transactions on Vehicular Technology [online]. 2019, 68(12), p. 1149211504. ISSN 0018-9545. Available from: https://doi.org/10.1109/TVT.2019.2948192

[7] WANG, F., ZHANG, J., XU, X., CAI, Y., ZHOU, Z., SUN, X. A comprehensive dynamic efficiency-enhanced energy management strategy for plug-in hybrid electric vehicles. Applied Energy [online]. 2019, 247, p. 657-669. ISSN 0306-2619. Available from: https://doi.org/10.1016/j.apenergy.2019.04.016

[8] HUBKA, L. Electric cars in the Czech Republic - the analysis of $\mathrm{CO}_{2}$ emissions reduction. In: 2019 20th International Carpathian Control Conference: proceedings [online]. ICCC, 2019. Available from: https://doi.org/10.1109/ CarpathianCC.2019.8765971

[9] CANAlS, C., MARTINEZ-LASERNA, E., AMANTE-GARCIA, B., NIETO, N. Sustainability analysis of the electric vehicle use in Europe for CO2 emissions reduction. Journal of Cleaner Production [online]. 2016, 127, p. 425-437. ISSN 0959-6526. Available from: https://doi.org/10.1016/j.jclepro.2016.03.120

[10] WEISS, M., CLOOS, KC., HELMERS, E. Energy efficiency trade-offs in small to large electric vehicles. Enviromental Science Europe [online]. 2020, 32(1), 46. eISSN 2190-4715. Available from: https://doi.org/10.1186/s12302-020-00307-8

[11] JAGELCAK, J., KIKTOVA, M., STOPKOVA, M. The application of the verified gross mass of intermodal loading units in the conditions of the Slovak Republic. Nase More [online]. 2018, 65(4), p. 218-223. Available from: https://doi.org/10.17818/NM/2018/4SI.10

[12] MASSIANI, J., WEINMANN, J., Estimating electric car's emissions in Germany: an analysis through a pivotal marginal method and comparison with other methods. Economics and Policy of Energy and the Environment. 2012, 2. ISSN 2280-7659.

[13] Transport emissions - Eurostat [online]. 2018. Available from: https://ec.europa.eu/clima/policies/transport_en

[14] KONECNY, V., PETRO, F. Calculation of selected emissions from transport services in road public transport. In: 18th International Scientific Conference Logi: proceedings [online]. 2017. Available from: https://doi.org/10.1051/ matecconf/201713400026

[15] OSIPOWOCZ, T., ABRAMEK, K. F., MATUSZAK, Z., JASKIEWICZ, M., LUDWINEK, K., POLIAK, M. The analysis of technical condition common rail fuel system components. In: 11th International Science and Technical Conference Automotive Safety Automotive Safety: proceedings [online]. 2018. Available from: https://doi.org/10.1109/ AUTOSAFE.2018.8373304

[16] Project of electric vehicle - Edison [online] [accessed 2019-12-21]. Available from: http://www.edison.uniza.sk/en/ electric_vehicle 
[17] QIN, Z., ZHANG, D., HAN, Y., LUO, Y. Dynamic coordinated control of a downhill safety assistance system for hybrid electric buses. Proceedings of the Institution of Mechanical Engineers, Part D: Journal of Automobile Engineering [online]. 2017, 231(8), p. 1034-1045. ISSN 0954-4070, eISSN 2041-2991. Available from: https://doi.org/10.1177/0954407016670295

[18] MAHA MSR 1050. User manual.

[19] EN 30 0556. Road vehicles. Speed characteristics. Test methods.

[20] SARKAN, B., STOPKA, O. Quantification of road vehicle perormance parameters under laboratory conditions. Advances in Science and Technology - Research Journal [online]. 2018, 12(3), p. 16-23. ISSN 2299-8624. Available from: https://doi.org/10.12913/22998624/92107

[21] SARKAN, B., STOPKA, O., CHOVANCOVA, M., KURANC, A. Simulating real driving conditions on the single roller dynamometer: a case study in terms of the fuel consumption measurement. In: 11th International Scientific and Technical Conference on Automotive Safety: proceedings. 2018.

[22] Commission Regulation (EU) No 1014/2010 of 10 November 2010 on monitoring and reporting of data on the registration of new passenger cars pursuant to Regulation (EC) No 443/2009 of the European Parliament.

[23] EN 50470-1/A1. Electricity metering equipment (a.c.). Part 1: General requirements, tests and test conditions. Metering equipment (class indexes A, B and C).

[24] MILOJEVIC, S. Sustainable application of natural gas as engine fuel in city buses-benefit and restrictions. Journal of Applied Engineering Science [online]. 2017, 15(1), p. 81-88. ISSN 2247-3769. Available from: https://doi.org/10.5937/ jaes15-12268

[25] JILEK, P., SEFCIK, I., VERNER, J., BERG, J. System allowing adhesion force change of road vehicle. In: 18th International Scientific Conference on Engineering for Rural Development ERD 2019: proceedings. 2019. p. 1876-1882. Available from: https://doi.org/10.22616/ERDev2019.18.N051

[26] SHEN, Y., VIEHMANN, A., RINDERKNECHT, S. Investigation of the power losses of the hybrid transmission DE-REX based on modeling and measurement. Proceedings of the Institution of Mechanical Engineers Part D - Journal of Automobile Engineering [online]. 2019, 233(14), p. 3646-3657. ISSN 0954-4070, eISSN 2041-2991. Available from: https://doi.org/10.1177/0954407019829655

[27] VRABEL, J., STOPKA, O., RIEVAJ, V., SARKAN, B., PRUSKOVA, K., MICHALK, P. Measuring the resistance of tires for passenger vehicle against the rolling and sliding on loading area of the flatbed truck when providing the transport services. Communications - Scientific Letters of the University of Zilina [online]. 2016, 18(2), p. 124-128. ISSN 13354205. Available from: http://komunikacie.uniza.sk/index.php/communications/article/view/343

[28] RIEVAJ, V., GANA, J., SYNAK, F. Comparison of emissions depending on the type of vehicle engine. Logistics and Sustainable Transport [online]. 2019, 10(1), p. 45-54. eISSN 2232-4968. Available from: https://doi.org/10.2478/jlst2019-0004

[29] Corrigendum to Commission Regulation (EU) 2017/1154.

[30] CHEN, Z., LIU, Y., FU, Y., XU, X. Motor-torque-limited power-on upshift control in electric vehicles with automatic transmissions. Proceedings of the Institution of Mechanical Engineers Part D: Journal of Automobile Engineering [online]. 2016, 230(1), p. 18-36. ISSN 0954-4070, eISSN 2041-2991. Available from: https://doi.org/10.1177/0954407015577309

[31] HUI, C., WANG, Y. Effects analysis and modeling of different transmission running conditions for transmission efficiency. In: SAE 2016 World Congress and Exhibition: proceedings [online]. 2016. ISSN 0148-7191, eISSN 2688-3627. Available from: https://doi.org/10.4271/2016-01-1096

[32] PHILIPS, P. J., ORPE, M., VASQUEZ, G. Decoupling vehicle work from powertrain properties in vehicle fuel consumption. SAE Intarnational Journal of Fuels and Lubricants. 2018, 11(4), p. 533-543. ISSN 1946-3952, eISSN 1946-3960. Available from: https://doi.org/10.4271/2018-01-0322

[33] JABLONICKY, J., HUJO, L., TKAC, Z., KOSIBA, J., ZIKLA, A. Comparison of two designs of differential planetary gear with differential in output. Materials, Technologies and Quality Assurance [online]. 2013, 801, p. 13-18. ISSN 1662-8985. Available from: https://doi.org/10.4028/www.scientific.net/AMR.801.13

[34] TAVARESS, A. A., FORNASA, I., CALIPA-LUGUE, J. C. Power losses analysis and efficiency evaluation of an electric vehicle conversion. In: IEEE International Conference on Electrical Systems for Aircraft, Railway, Ship Propulsion and Road Vehicles and International Transportation Electrification Conference ESARS-ITEC: proceedings [online]. 2018. Available from: https://doi.org/10.1109/ESARS-ITEC.2018.8607322

[35] ZHU, C., CHEN, Q., ZHUANG, Y., GAO, B., TIAN, M. Research on tire stiffness and rolling resistance matching of in-wheel-motor direct drive electric vehicle. Jixie Gongcheng Xuebao / Journal of Mechanical Engineering [online]. 2019, 55(22), p. 41-51. ISSN 0577-6686. Available from: https://doi.org/10.3901/JME.2019.22.041

[36] KHALIGH, A., D‘ANTONIO, M. Global trends in high-power on board chargers for electric vehicles. IEEE Transactions on Vehicular Technology [online]. 2019, 68(4), p. 3306-3324. ISSN 0018-9545. Available from: https://doi.org/10.1109/ TVT.2019.2897050 
[37] DING, Z. Electric vehicle controller driving efficiency and power batteries pack capacity detecting test-bed design. IPPTA: Quarterly Journal of Indian Pulp and Paper Technical Association. 2018, 30(5). ISSN 0379-5462.

[38] RAJABZADEH, M., BATHAEE, S. M. T., GOLKAR, M. A. Advanced DC-link voltage regulation of fuel-cell electric vehicle. COMPEL - The International Journal for Computation and Mathematics in Electrical and Electronic Engineering [online]. 2016, 35(3), p. 943-958. ISSN 0332-1649. Available from: https://doi.org/10.1108/COMPEL-042015-0166

[39] SHAROVA, V., MORETTI, A., DIEMANT, T., VARZI, A., BEHM, R. J., PASSERINI, S. Comparative study of imidebased Li salts as electrolyte additives for Li-ion batteries. Journal of Power Source [online]. 2018, 375, p. 43-52. ISSN 0378-7753. Available from: https://doi.org/10.1016/j.jpowsour.2017.11.045

[40] SANTOS, A. G., VIEIRA, M. R. S., URTIGA, S. L., SILVA, F. J., Influence of Sn addition on the corrosion resistance and recharge capacity of $\mathrm{Pb}-1,5 \mathrm{wt} \% \mathrm{Sn}$ alloy for positive grids of lead acid batteries. Materia [online]. 2019, 24(1). ISSN 1517-7076. Available from: https://doi.org/10.1590/S1517-707620190001.0640

[41] ZHUFRI, A., ZHANG, J. An electrical model for energy efficiency evaluation of NiMh batteries. In: 30th Annual IEEE Canadian Conference on Electrical and Computer Engineering IEEE CCECE 2017: proceedings. 2017. ISBN: 978-1-5090-5538-8.

[42] LEBKOWSKI, A. Studies of energy consumption by a city bus powered by a hybrid energy storage system in variable road conditions. Energies [online]. 2019, 12(5), 951. ISSN eISSN 1996-1073. Available from: https://doi.org/10.3390/ en12050951 